\title{
First report of scuticociliatosis caused by Uronema sp. in ornamental reef fish imported into Brazil
}

\author{
Primeiro relato de scuticociliatose causada por Uronema sp. em peixes ornamentais de recife \\ importados para o Brasil \\ Pedro Henrique Magalhães Cardoso ${ }^{1 *}$; Simone de Carvalho Balian ${ }^{1}$; Eliana Reiko Matushima ${ }^{2}$; \\ Santiago Benites de Pádua ${ }^{3}$; Maurício Laterça Martins ${ }^{4}$

\begin{abstract}
${ }^{1}$ Departamento de Medicina Veterinária Preventiva e Saúde Animal, Faculdade de Medicina Veterinária e Zootecnia, Universidade de Sáo Paulo - USP, São Paulo, SP, Brasil

${ }^{2}$ Departamento de Patologia, Faculdade de Medicina Veterinária e Zootecnia, Universidade de São Paulo - USP, São Paulo, SP, Brasil

${ }^{3}$ Saúde Aquática - AQUIVET, São José do Rio Preto, SP, Brasil

${ }^{4}$ Laboratório de Saúde Aquática - AQUOS, Departamento de Aquicultura, Universidade Federal de Santa Catarina - UFSC, Florianópolis, SC, Brasil
\end{abstract}

Received March 31, 2017

Accepted May 11, 2017

\begin{abstract}
Scuticociliatosis, which is caused by an opportunistic ciliate protozoan, is responsible for significant economic losses in marine ornamental fish. This study reports the occurrence of Uronema sp., which was found to be parasitizing three species of marine reef fish imported into Brazil and maintained in quarantine: Vanderbilt's Chromis (Chromis vanderbilti), blue-green damselfish (Chromis viridis), and sea goldie (Pseudanthias squamipinnis). During the quarantine period, some fish presented with behavioral disorders and hemorrhages and ulcerative lesions on the body surface. Histopathological analysis showed hemorrhages, inflammation comprising mononuclear and granular cells in the skeletal muscle, and necrosis of the skin and the secondary lamellae of the gills, and parasites were also observed in the renal capsule. The absence of transboundary measures available to prevent the occurrence of ornamental fish diseases is also discussed.
\end{abstract}

Keywords: Ornamental fish, Chromis, Pseudanthias, Scuticociliatia, transboundary disease, histopathology.

\section{Resumo}

Scuticociliatose, causada por protozoários ciliados oportunistas, é responsável por perdas econômicas significativas em peixes ornamentais marinhos. O presente estudo relata a ocorrência de Uronema sp., parasitando três espécies de peixes ornamentais de recife importados para o Brasil e mantidos em quarentena: Vanderbilt's Chromis (Chromis vanderbilti), blue-green damselfish (Chromis viridis), e sea goldie (Pseudanthias squamipinnis). Durante o período de quarentena, alguns peixes apresentaram alteraçôes comportamentais tais com hemorragias e lesóes ulcerativas na superfície da pele. A histopatologia mostrou hemorragias, inflamação com células mononucleares e granulares na musculatura, e necrose da pele e lamelas secundárias das brânquias, e parasitas também foram observados na cápsula renal. A ausência de medidas transfronteiriças disponíveis para prevenir a ocorrência de doenças de peixes ornamentais também é discutida.

Palavras-chave: Peixes ornamentais, Chromis, Pseudanthias, Scuticociliatia, doença transfronteiriça, histopatologia.

\section{Introduction}

Scuticociliatosis, a severe disease that compromises the health of marine ornamental fish, is caused by marine ciliates belonging to the subclass Scuticociliatia. Uronema marinum Dujardin, 1841 was first reported in nine fish species from the Atlantic and Pacific Oceans maintained in the New York Aquarium

*Corresponding author: Pedro Henrique Magalhães Cardoso. Departamento de Medicina Veterinária Preventiva e Saúde Animal, Faculdade de Medicina Veterinária e Zootecnia, Universidade de São Paulo - USP, Rua Professor Orlando Marques Paiva, 87, CEP 05508-270, São Paulo, SP, Brasil.

e-mail: pedrohenriquemedvet@usp.br
(CHEUNG et al., 1980). The disease has a worldwide distribution and causes lesions on the body surface and gills in addition to systemic infection (PIAZZON et al., 2014), being responsible for high mortality rates. The fish species most affected are the olive flounder Paralichthys olivaceus (IGLESIAS et al., 2001; JIN et al., 2009; MOUSTAFA et al., 2010a), turbot Scophthalmus maximus (IGLESIAS et al., 2001; WHANG et al., 2013), sea bass Dicentrarchus labrax (WHANG et al., 2013), Southern bluefin tuna Thunnus maccoyii (MUNDAY et al., 1997; GARZA et al., 2017), grouper Polyprion oxygeneios, yellowtail kingfish Seriola lalandi (SMITH et al., 
2009), and silver pomfret Pampus argenteus (AZAD et al., 2007). The most pathogenic scuticociliates are Pseudocohnilembus persalinus Evans \& Thompson, 1964, Pseudocohnilembus longisetus Evans \& Thompson, 1964, U. marinum, and Miamiensis avidus Thompson \& Moewus, 1964 (GARZA et al., 2017; MOUSTAFA et al., 2010b; WHANG et al., 2013).

Uronema Lagerheim, 1887 is an opportunistic, free-living ciliate protozoan that parasitizes mostly the body surface, gills, and fins of marine fish. It tolerates a wide range of salinity, of 15-35 ppt (CROSBIE \& MUNDAY, 1999) and causes severe disease in ornamental fish, from which fish farmers can suffer heavy economic losses if the disease is not treated sufficiently rapidly (CHEUNG et al., 1980; GILL \& CALLINAN, 1997; NOGA, 2010).

Pathogenicity caused by this parasite is more severe in environments with high levels of bacteria, nutrients, and organic matter (URRUTXURTU et al., 2003). It can be found parasitizing both farmed and ornamental marine fish (AZAD et al., 2007; DECLERCQ et al., 2014).

The parasite produces proteases responsible for digestion of the host's tissues and proteins (AL-MARZOUK \& AZAD, 2007). It also provokes asymptomatic changes and frequent macroscopic and ulcerative lesions on the body surface and fins, exophthalmia, and a swollen visceral cavity. Infected fish may also present with internal changes such as brain liquefaction, hemorrhages, and muscle ulceration (AZAD et al., 2007; IGLESIAS et al., 2001; JIN et al., 2009; MOUSTAFA et al., 2010a, b; ROSSTEUSCHER et al., 2008), these being readily observed on histopathological exam.

Microscopic observation shows the parasites feeding mostly on cell tissue of the gills and muscles (IGLESIAS et al., 2001; JIN et al., 2009; PIAZZON et al., 2014; ROSSTEUSCHER et al., 2008).

This study reports the occurrence of scuticociliatosis followed by an acute infection in three ornamental marine reef fish species imported into Brazil, Vanderbilt's Chromis (Chromis vanderbilti), blue-green damselfish (Chromis viridis), and sea goldie (Pseudanthias squamipinnis), as well as chronic lesions and recovery after treatment of $C$. viridis.

\section{Materials and Methods}

Ornamental marine fish $C$. vanderbilti $(n=3), C$. viridis $(n=10)$, and $P$. squamipinnis $(n=3)$ were obtained from quarantine following importation into São Paulo State, Southeast Brazil. The fish had been captured from their natural environment in Kenia, Indian Ocean and were maintained in aquaria $\left(2.8 \mathrm{~m}^{3}\right.$, with a recirculating system) and fed five times a day with the commercial diet (Tetra ${ }^{\circledR}$ Marine flakes and granules). The monitored water temperature was maintained at $26{ }^{\circ} \mathrm{C}$, salinity $29 \mathrm{ppt}$, dissolved oxygen $5 \mathrm{mg} \mathrm{L}^{-1}$, $\mathrm{pH} 8.2$, and total ammonia $<0.1 \mathrm{mgL}^{-1}$.

Six $C$. viridis and two P. squamipinnis had arrived dead in the transport bags and, $24 \mathrm{~h}$ following acclimation in quarantine, other fish presented with behavioral disorders such as gasping, swimming on water surface, starvation and lethargy and depigmented skin lesions (Figure 1a); the latter culminated, in $<48 \mathrm{~h}$, in hemorrhagic and ulcerative lesions and fish death.

The diseased fish were examined by a qualified veterinary service as part of the disease diagnostic investigation. Scrapings of the body surface and gills and internal examination were performed.

Five specimens of $C$. viridis and one of $P$. squamipinnis with lesions on the body surface were euthanized by brain concussion and fixed in buffered 10\% formalin solution for histopathology. Fragments of lesions, gills, and internal organs were carefully removed and processed according to an accepted histological process, embedded in paraffin as posterior cross sections of $5 \mu \mathrm{m}$, and stained with hematoxylin-eosin. The slides were examined and photomicrographs taken using an Olympus BX60 ${ }^{\circledR}$ (Olympus Optical Co., Ltd., Tokyo, Japan) equipped with an image analyzer (Image Pro Plus 6.1 for Windows, Copyright ${ }^{\circledR}$ 1993-2006, Media Cybernetics, Inc.).

Other fish from the same imported group (20 Chromis vanderbilti, 150 Chromis viridis, and 20 Pseudanthias squamipinnis) showed mild clinical signs but with no visible lesions, and these were maintained in a bath, incorporating a recirculating system, with $37 \%$ formalin at a concentration of $0.125 \mathrm{~mL} \mathrm{~L}^{-1}$ of water for $60 \mathrm{~min}$, with constant aeration. After treatment, they were transferred to the hospital aquarium (total volume $0.45 \mathrm{~m}^{3}$ ) where they received prophylactic treatment with neomycin sulfate at $6 \mathrm{~g} 100 \mathrm{~L}^{-1}$ for 5 days. During this period, the fish were treated with two further baths of formalin $\left(0.125 \mathrm{~mL} \mathrm{~L}^{-1}\right.$ of water for $60 \mathrm{~min}$, 3 and 7 days after harvesting). After treatment, 10 specimens of $C$. viridis were collected for skin scrapings analysis. Some fish showing clinical recovery and healing of ulcerative lesions presented with blackish skin nodules, and lesions of one C. viridis were collected for histopathological analysis.

\section{Results}

Fresh mounts of skin scrapings from all diseased fish showed a heavy parasite load of a pyriform-shaped ciliate protozoan suggestive of Uronema sp. (Figure 1a). No other type of parasite was found.

Histopathological analysis showed invasion by scuticociliates in the skin layers, compromising the skeletal muscle. Hemorrhages, inflammation composed by mononuclear and granular cells in the skeletal muscle, cutaneous necrosis, muscle fiber edema, and necrotizing myositis were observed. In the gills, the parasites had caused necrosis of the secondary lamellae, and an inflammatory infiltrate of eosinophilic granulocytes was observed; this latter feature was also observed in the renal capsule.

Seven days post treatment, the scrapings from 10 C. viridis individuals showed no parasites. These fish were then isolated and monitored for observation of blackish nodules secondary to tissue repair (Figure 2a). The presence of these nodules renders such fish commercially worthless. These fish showed granulomatous lesions on the skin (Figure 2b, c) and adjacent skeletal muscle (Figure 2d), the lesions in most cases containing deposits of brownish pigment and with a necrotic center. 

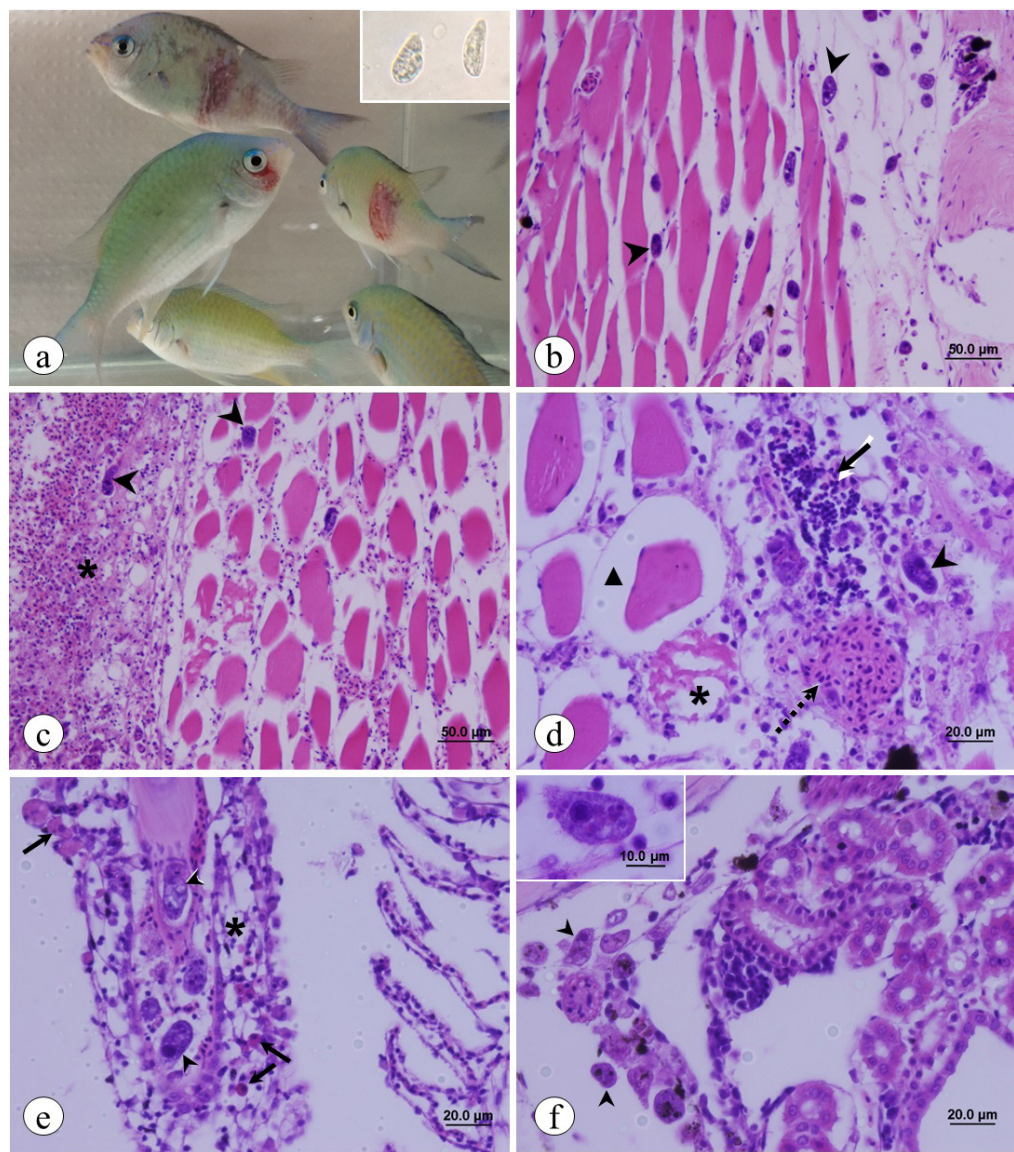

Figure 1. Chromis viridis showing hemorrhagic ulcerative lesions on the skin (a); presence of scuticociliates invading the subcutaneous tissue and skeletal muscle (a-b, arrow heads), with necrosis, hemorrhages and inflammatory infiltrate in the subcutaneous tissue (c - asterisk); edema of the muscular fiber $(\mathrm{d}-\boldsymbol{\Delta})$, necrotizing myositis ( $\mathrm{d}$ - asterisk) with mononuclear inflammatory focus ( $\mathrm{d}$ - continuous arrow) and hemorrhages ( $\mathrm{d}$ - dotted arrow); protozoans invading the gill tissue (e - arrow head) with vacuolar degeneration, necrosis (e - asterisk) and inflammatory infiltrate composed by eosinophilic granulocytes (e - continuous arrows); parasites invading the renal capsule ( $\mathrm{f}$ - arrow head). Stained with hematoxylin-eosin (b-f).
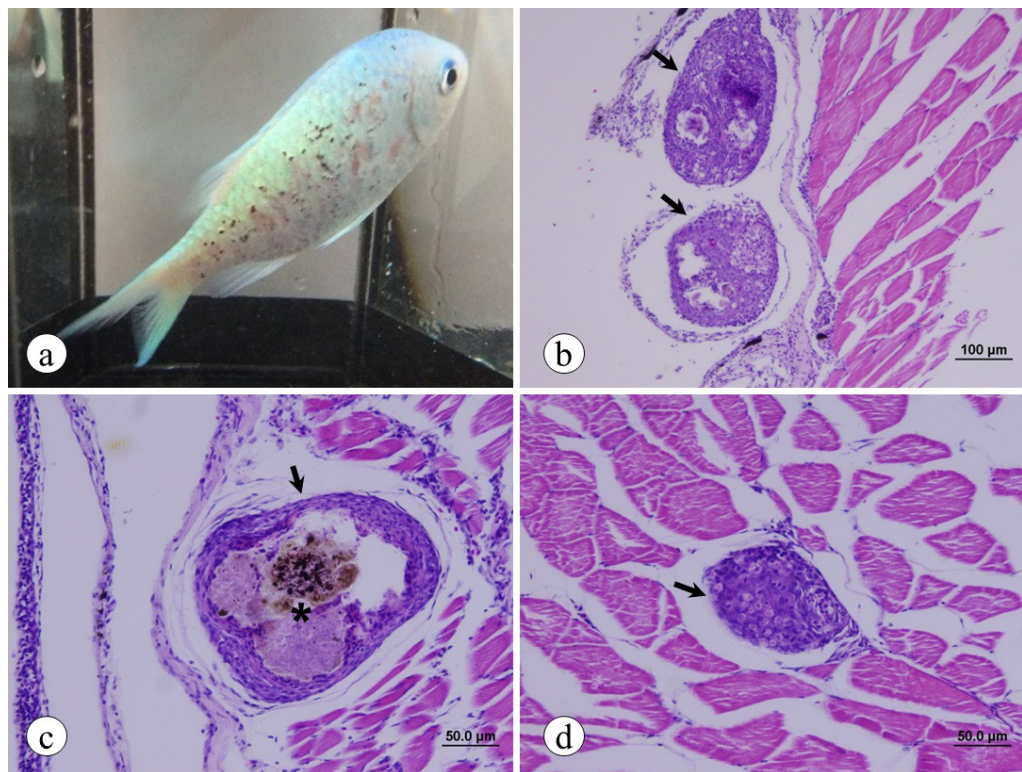

Figure 2. Chromis viridis showing blackish nodules on the skin and complete healing of the ulcerative lesions (a). Dermatitis and reminiscent granulomatous myositis (b-d) with some granuloma containing deposits of brownish pigmentation into the necrotic site (c - asterisk). Stained with hematoxylin-eosin (b-d). 


\section{Discussion}

Improved water quality and earlier diagnostic and therapeutic measures with freshwater baths followed by formalin treatment enhance the prognosis of this condition (personal communication). In vitro studies showed the efficacy of $100-200 \mathrm{mg} \mathrm{L}^{-1}$ formalin baths for 120 and 60 min against ciliate protozoans; weak $\left(25-50 \mathrm{mg} \mathrm{L}^{-1}\right)$ and strong (167-250 $\left.\mathrm{mg} \mathrm{L}^{-1}\right)$ formalin baths are commonly used to treat ornamental fish (CROSBIE \& MUNDAY, 1999).

In contrast, in the absence of early diagnosis and treatment, the disease can develop rapidly, affecting not only the body surface but also the muscles, visceral cavity, kidney, pancreas, liver, swim bladder, and brain, causing deep ulceration and death (GILL \& CALLINAN, 1997; IGLESIAS et al., 2001; AZAD et al., 2007; JIN et al., 2009). Recovered fish lose their natural color and present with blackish areas on the body surface, rendering them worthless commercially.

Scuticociliatosis is frequently accompanied by bacterial infection, as previously reported in the seahorse Hippocampus kuda (DECLERCQ et al., 2014). Mortality in Japanese flounder can reach $70-80 \%$, as reported by Moustafa et al. (2010a). The lesions herein observed such as hemorrhages, inflammatory reaction in the skeletal muscle and necrosis of the secondary lamellae were similar to those previously related (MOUSTAFA et al., 2010a).

The lack of epidemiological data on fish diseases and asymptomatic carriers, allied to the absence of control by post-frontier importers, increases the risk of diseases in native fish and subsequent economic losses. Importer facilities must adopt biosecurity measures to prevent the introduction and dissemination of diseases. The quarantine period for fish in Brazil is only 7 days (BRASIL, 2008), which is not sufficient in most cases to detect the etiological agent(s). Australia and New Zealand carry out rigorous risk analysis and quarantine for exotic animals, comprising three weeks of quarantine and regular diagnostic procedures (WHITTINGTON \& CHONG, 2007).

Taking into account the severity of scuticociliatosis in C. viridis and the transboundary potential of Uronema sp., it is necessary not only to improve the best management practices but also to implement biosecurity with rapid, accurate diagnosis to minimize the risk of economic losses and introduction of new diseases to fish farms.

\section{References}

Al-Marzouk A, Azad IS. Growth kinetics, protease activity and histophagous capability of Uronema sp. infesting cultured silver pomfret Pampus argenteus in Kuwait. Dis Aquat Organ 2007; 76(1): 49-56. PMid:17718165. http:// dx.doi.org/10.3354/dao076049.

Azad IS, Al-Marzouk A, James CM, Almatar S, Al-Gharabally H. Scuticociliatosis-associated mortalities and histopathology of natural infection in cultured silver pomfret (Pampus argenteus Euphrasen) in Kuwait. Aquaculture 2007; 262(2-4): 202-210. http://dx.doi.org/10.1016/j. aquaculture.2006.10.033.

Brasil. Ministério da Agricultura, Pecuária e Abastecimento, Secretaria de Defesa Agropecuária. Instrução Normativa $N^{o}$ 18, de 13 de maio de 2008. Diário Oficial da União; Brasília; 14 Mar 2008.
Cheung PJ, Nigrelli RF, Ruggieri GD. Studies on the morphology of Uronema marinum Dujardin (Ciliatea: Uronematidae) with a description of the histopathology of the infection in marine fishes. J Fish Dis 1980; 3(4): 295-303. http://dx.doi.org/10.1111/j.1365-2761.1980.tb00400.x.

Crosbie PBB, Munday BL. Environmental factors and chemical agents affecting the growth of the pathogenic marine ciliate Uronema nigricans. Dis Aquat Organ 1999; 36(3): 213-219. PMid:10401587. http://dx.doi. org/10.3354/dao036213.

Declercq AM, Chiers K, Van Den Broeck W, Rekecki A, Teerlinck S, Adriaens D, et al. White necrotic tail tips in estuary seahorses, Hippocampus kuda, Bleeker. J Fish Dis 2014; 37(5): 501-504. PMid:23763536. http:// dx.doi.org/10.1111/jfd.12138.

Garza JB, Bott NJ, Hammond MD, Shepherd N, Nowak BF. Molecular characterisation of Miamiensis avidus (Ciliophora: Scuticociliata) from ranched southern bluefin tuna, Thunnus maccoyii off Port Lincoln, South Australia. Aquaculture 2017; 469: 44-49. http://dx.doi.org/10.1016/j. aquaculture.2016.11.040.

Gill PA, Callinan RB. Ulcerative dermatitis associated with Uronema sp Infection of farmed sand whiting Sillago ciliata. Aust Vet J 1997; 75(5): 357. PMid:9196825. http://dx.doi.org/10.1111/j.1751-0813.1997. tb15714.x.

Iglesias R, Paramá A, Alvarez MF, Leiro J, Fernández J, Sanmartín ML. Philasterides dicentrarchi (Ciliophora, Scuticociliatida) as the causative agent of scuticociliatosis in farmed turbot Scophthalmus maximus in Galicia (NW Spain). Dis Aquat Organ 2001; 46(1): 47-55. PMid:11592702. http://dx.doi.org/10.3354/dao046047.

Jin CN, Harikrishnan R, Moon YG, Kim MC, Kim JS, Balasundaram C, et al. Histopathological changes of korea cultured olive flounder, Paralichthys olivaceus due to scuticociliatosis caused by histophagous scuticociliate, Philasterides dicentrarachi. Vet Parasitol 2009; 161(3-4): 292 301. PMid:19286321. http://dx.doi.org/10.1016/j.vetpar.2009.01.033.

Moustafa EMM, Naota M, Morita T, Tange N, Shimada A. Pathological study on the scuticociliatosis affecting farmed Japanese flounder (Paralichthys olivaceus) in Japan. JVet Med Sci 2010a; 72(10): 1359-1362. PMid:20460839. http://dx.doi.org/10.1292/jvms.10-0026.

Moustafa EMM, Tange N, Shimada A, Morita T. Experimental scuticociliatosis in Japanese flounder (Paralichthys olivaceus) infected with Miamiensis avidus: pathological study on the possible neural routes of invasion and dissemination of the scuticociliate inside the fish body. $J$ Vet Med Sci 2010b; 72(12): 1557-1563. PMid:20675963. http://dx.doi. org/10.1292/jvms.10-0214.

Munday BL, O’Donoghue PJ, Watts M, Rough K, Hawkesford T. Fatal encephalitis due to the scuticociliate Uronema nigricans in sea-caged, southern bluefin tuna Thunnus maccoyii. Dis Aquat Organ 1997; 30(1): 17-25. http://dx.doi.org/10.3354/dao030017.

Noga EJ. Fish disease: diagnosis and treatment. 2nd ed. Iowa: WilleyBlackwell; 2010.

Piazzon MC, Leiro J, Lamas J. Reprint of "Fish immunity to scuticociliate parasites". Dev Comp Immunol 2014; 43(2): 280-289. PMid:24309548. http://dx.doi.org/10.1016/j.dci.2013.11.015.

Rossteuscher S, Wenker C, Jermann T, Wahli T, Oldenberg E, SchmidtPosthaus H. Severe Scuticociliate (Philasterides dicentrarchi) Infection in a population of sea dragons (Phycodurus eques and Phyllopteryx taeniolatus). Vet Pathol.2008; 45(4): 546-550. PMid:18587104.

Smith PJ, McVeagh SM, Hulston D, Anderson SA, Gublin Y. DNA identification of ciliates associated with disease outbreaks in a New Zealand marine fish hatchery. Dis Aquat Organ 2009; 86(2): 163-167. PMid:19902845. http://dx.doi.org/10.3354/dao02113. 
Urrutxurtu I, Orive E, Sota A. Seasonal dynamics of ciliated protozoa and their potential food in an eutrophic estuary (Bay of Biscay). Estuar Coast Shelf Sci 2003; 57(5-6): 1169-1182. http://dx.doi.org/10.1016/ S0272-7714(03)00057-X.

Whang I, Kang HS, Lee J. Identification of scuticociliates (Pseudocohnilembus persalinus, P. longisetus, Uronema marinum and Miamiensis avidus) based on the cox1 sequence. Parasitol Int 2013; 62(1): 7-13. PMid:22951379. http://dx.doi.org/10.1016/j.parint.2012.08.002.

Whittington RJ, Chong R. Global trade in ornamental fish from an Australian perspective: the case for revised import risk analysis and management strategies. Prev Vet Med 2007; 81(1-3): 92-116. PMid:17485126. http:// dx.doi.org/10.1016/j.prevetmed.2007.04.007. 